\title{
Chemical Methods for the Synthesis and Modification of Neoclerodane Diterpenes
}

\author{
Anthony Lozama ${ }^{a, b}$ and Thomas E. Prisinzano ${ }^{b}$ \\ aDivision of Medicinal \& Natural Products Chemistry, College of Pharmacy, The University of lowa, \\ lowa City, lowa 52240 USA \\ bDepartment of Medicinal Chemistry, College of Pharmacy, The University of Kansas Lawrence, \\ Kansas 66046 USA
}

\section{Abstract}

Diterpenes are a structural class of molecules that are derived from four isoprene subunits and are widespread throughout nature. A number of neoclerodane diterpenes have been found to have biological activity but a limited number of chemical investigations have been conducted. Recently, the neoclerodane diterpene, salvinorin A (12) has been investigated due to its unique pharmacological profile. This review will discuss the chemical methods used to chemically modify and synthesize 12.

\section{Keywords}

diterpene; neoclerodane; salvinorin A; Salvia divinorum

Terpenes are a wide variety of 10-carbon skeletons formed from the coupling of two isoprene subunits. 1 They are ubiquitous in nature as they are used as biosynthetic building blocks in many living organisms including plants and animals. 1 There are many different types of terpenes and they are classified by their structure. 1 Diterpenes are one class that possess a core 20 -carbon skeleton and are found in many different plant families and some animals. ${ }^{1}$ They are biosynthesized by two different pathways, the mevalonic acid pathway (MVA) or the deoxyxylulose phosphate pathway (DOXP). ${ }^{2-} 5$ Diterpenes are of interest as many have been found to have biological activity. Some biologically active diterpenes include taxol (1), cafestol (2) and kahweol (3) (Figure 1). Diterpenes 1-3, isolated from Taxus brevifolia ${ }^{6}$ and Coffea arabica respectively, 7,8 all display anticancer properties.

One type of structural class of diterpenes are clerodanes which are found in many different plant families and contain four contiguous stereocenters contained in a cis or trans decalin (4). ${ }^{9,10}$ Various clerodane diterpenes have been isolated and displayed biological activity. These include columbin (5), isolated from the roots of Calumbae radix ${ }^{11}$ which has cancer chemo-preventive properties ${ }^{12}$ and clerocidin (6), isolated from Oidiodendron truncatum ${ }^{13}$ which has shown antibiotic activity. ${ }^{13}$ Terpentecin (7), a microbial clerodane diterpene from

\footnotetext{
(C) 2009 Elsevier Ltd. All rights reserved.
}

Publisher's Disclaimer: This is a PDF file of an unedited manuscript that has been accepted for publication. As a service to our customers we are providing this early version of the manuscript. The manuscript will undergo copyediting, typesetting, and review of the resulting proof before it is published in its final citable form. Please note that during the production process errors may be discovered which could affect the content, and all legal disclaimers that apply to the journal pertain. 
Streptomyces sp., has shown to be an antitumor antibiotic that targets DNA topoisomerase II. 14

Neoclerodanes are a subtype of clerodane diterpenes that share the same absolute stereochemistry of clerodin $(\mathbf{8}) .^{2}$ Neoclerodane $\mathbf{8}$, displays antifeedant properties and inhibits insect growth. ${ }^{15}$ These attributes have also been seen in other neoclerodanes such as ajugatansin A1 (9), and tafricanin A (10). These discoveries have implications for agriculture, as neoclerodane diterpenes, may have potential use as environmentally benign pest deterrents. 16 One such example is callicarpenal (11), which has been shown to be a mosquito bite detterant $^{17,18}$ and a repellant of the blacklegged tick, lxodes scapularis and the lone star tick, Amblyomma americanum. ${ }^{19}$

Despite their biological properties, few synthetic works have been published on neoclerodane diterpenes. ${ }^{9,20-22}$ One neoclerodane diterpene that has been investigated recently is salvinorin A (12). Neoclerodane 12 is isolated from the leaves of Salvia divinorum, and has shown to have hallucinogenic effects. ${ }^{23-26}$ However, 12 is unlike classical hallucinogens, as it does not interact with the $5-\mathrm{HT}_{2 \mathrm{~A}}$ receptor. ${ }^{25,27}$ Rather, 12 is a selective $\kappa$ opioid agonist. ${ }^{28}$ This was the first report of a neoclerodane diterpene to be active at opioid receptors, ${ }^{28}$ thus establishing neoclerodane diterpenes as a novel scaffold for opioid ligands. ${ }^{27,29}$ The chemical modification of 12 has been undertaken by several groups, including our own, to explore its chemical reactivity and to develop analogues that explore its pharmacophore at opioid receptors. ${ }^{30-35}$

Neoclerodane $\mathbf{1 2}$ is a highly functionalized molecule with a tricyclic core structure and seven chiral centers. Feeding experiments with $\left[1-{ }^{13} \mathrm{C} ; 3,4-{ }^{2} \mathrm{H}_{2}\right]-1$-deoxy-D-xylulose (DOX) have shown that $\mathbf{1 2}$ is biosynthesized in a manner consistent with the deoxyxylulose phosphate pathway. ${ }^{36}$ The chiral center at the $\mathrm{C} 8$ position of $\mathbf{1 2}$ has shown to readily undergo epimerization under acidic or basic conditions (Figure 2). ${ }^{30-32,34,35}$ Epimerization at this center has shown to have great impact on biological activity. ${ }^{26,34,37-39}$ Despite these issues, several methods to explore the chemical reactivity of $\mathbf{1 2}$ have been developed.

Some of the initial chemical investigations of $\mathbf{1 2}$ attempted to remove the $\mathrm{C} 2$ acetate. Heating of $\mathbf{1 2}$ with strong base leads to the formation of $\mathbf{1 3}$ in $69 \%$ yield. ${ }^{40,41}$ Treatment of $\mathbf{1 2}$ with $\mathrm{KOH}$ in $\mathrm{CH}_{3} \mathrm{OH}$ leads to the oxidized products $\mathbf{1 4 a}$ and $\mathbf{1 5}$ in $53 \%$ and $37 \%$ yield respectively. 35 Using $\mathrm{Ba}(\mathrm{OH})_{2}$ in place of $\mathrm{KOH}$ in $\mathrm{CH}_{3} \mathrm{OH}$ gave $\mathbf{1 4 b}$ in $75 \%$ yield. ${ }^{34}$ This transformation was also attempted using $\mathrm{KCN}$ in refluxing $\mathrm{CH}_{3} \mathrm{OH} /$ tetrahydrofuran. ${ }^{42}$ While this method was able to remove the acetate, it led to epimerization at $\mathrm{C} 8$ as the major product with $51 \%$ yield. Selective removal of the $\mathrm{C} 2$ acetate of 12 was accomplished in $77 \%$ yield using $\mathrm{Na}_{2} \mathrm{CO}_{3}$ in $\mathrm{CH}_{3} \mathrm{OH},{ }^{30}$ yielding salvinorin B (16) (Figure 3). Ammonolyis of 12 using $\mathrm{NH}_{3}$ and $\mathrm{CH}_{3} \mathrm{OH}$ at $0^{\circ} \mathrm{C}$ gave 16 in $15 \%$ yield with its $\mathrm{C} 8$ epimer in a $1: 1$ ratio. $^{32}$

Several groups have explored the reactivity of the carbonyl at $\mathrm{C} 1$ on the A ring of 12.43,44 The reaction of 12 with $\mathrm{NaBH}_{4}$ at $35^{\circ} \mathrm{C}$ gives the corresponding $\mathrm{C} 1$ alcohol as a 1:1 mixture of the $\alpha$ and $\beta$ isomers in $40 \%$ yield. ${ }^{43}$ However, this method also causes epimerization at C8 in $40 \%$ yield. ${ }^{43}$ More recently, the reduction at $\mathrm{C} 1$ was improved by using an aqueous solution of $\mathrm{NaBH}_{4}$ in tetrahydrofuran. ${ }^{44}$ This method gave primarily the $\alpha$-alcohol 17 in $77 \%$ yield with no epimerization at $\mathrm{C} 8$ and minimal reduction at $\mathrm{C} 17 .{ }^{44}$

Conditions to selectively hydrolyze the $\mathrm{C} 4$ carbomethoxy group have also been identified. ${ }^{33 \text {, }}$

${ }^{34}$ Heating 12 with LiSEt in DMPU followed by treatment with $\mathrm{Ac}_{2} \mathrm{O}$ gave acid 18 and its C8 epimer in a 1.4:1 ratio with $73 \%$ overall yield. ${ }^{37}$ Alternatively, heating 12 with LiI in pyridine also hydrolyzed the $\mathrm{C} 4$ ester to the acid in a reported $70 \%$ yield and avoided $\mathrm{C} 2$ deacetylation. ${ }^{34}$ However, this method also caused C8 epimerization in a $1: 1$ ratio with $18 .{ }^{34}$ 
Treatment of 12 with excess DIBAL-H in THF at $-78^{\circ} \mathrm{C}$ reduced the $\mathrm{C} 17$ lactone to give lactol 19 as a $1: 1$ mixture of epimers in $65 \%$ yield. ${ }^{37,42}$ The reduction appears quite selective as other functional groups are not effected and epimerization did not occur. However, $\mathbf{1 9}$ is not stable and undergoes elimination overnight. ${ }^{37}$

The reaction of $\mathbf{1 2}$ with $\mathrm{NaIO}_{4}$ and a catalytic amount of $\mathrm{RuCl}_{3} \cdot \mathrm{H}_{2} \mathrm{O}$ in a mixture of acetonitrile/ $\mathrm{H}_{2} \mathrm{O} / \mathrm{CCl}_{4}$ affords acid 20 in $93 \%$ yield. ${ }^{45}$ Hydrogenation of $\mathbf{1 2}$ using rhodium on carbon gave $\mathbf{2 1}$ as a mixture of $\mathrm{C} 13$ epimers along with $\mathbf{2 2}^{46}$ in $59 \%$ and $28 \%$ yield respectively. If palladium on carbon is used for the hydrogenation, hydrogenolysis (22) is favored. ${ }^{36,43}$ Bromination of the furan at the 2-position 23a, can be achieved using $N$-bromosuccinamide (NBS) in acetonitrile ${ }^{46}$ or $\mathrm{CHCl}_{3}{ }^{40}$ with yields ranging from $10-60 \% .{ }^{40,46}$ Dibromination at the 2and-5 positions of the furan ring $\mathbf{2 3 b}$, can be achieved using $\mathrm{Br}_{2}$ and $\mathrm{CH}_{2} \mathrm{Cl}_{2}$ at $-30{ }^{\circ} \mathrm{C}$ in $52 \%$ yield. ${ }^{47}$ Treatment of 12 with $\mathrm{Br}_{2}$ and $\mathrm{CH}_{3} \mathrm{OH}$ affords dimethoxy, dihydrofuran 24 as a mixture of isomers in $61 \%$ yield. ${ }^{46}$ Finally, photo-oxidation of $\mathbf{1 2}$ gave the $\gamma$-hydroxy butenolides 25 as a $1: 3$ mixture of isomers in $25 \%$ yield. ${ }^{46}$

While $\mathbf{1 2}$ is a structurally complex natural product, a variety of reactions have been identified that have helped establish the chemical reactivity of 12, as well as prepare a wide array of analogues of 12 to explore its structure-activity relationships. ${ }^{48}$ Along with the work conducted to explore the chemical reactivity of $\mathbf{1 2}$, several groups have made attempts at the total synthesis of 12. ${ }^{49-53}$ To date, there have been two successful syntheses of 12. ${ }^{51,52}$ These efforts provide avenues to analogues that are difficult or unattainable by semi-synthesis.

In 2007, Evans and co-workers completed the first total synthesis of $\mathbf{1 2}$ in 33 steps with $4.5 \%$ overall yield. ${ }^{51}$ Evans envisioned $\mathbf{1 2}$ as being derived from macrolactone $\mathbf{2 6}$ through a transannular Michael reaction (Figure 4). ${ }^{54-56}$ Macrolactone 26 would then be assembled through the coupling of vinyl iodide 27 and aldehyde 28. Ketone $\mathbf{2 9}$ (Scheme 1) is prepared in $70 \%$ yield from the addition of propyne to 3 -furaldehyde followed by oxidation with $\mathrm{MnO}_{2}$. Reduction of 30 with $(R)$ - $\beta$-Methyl-oxazaborolidene gave alcohol 30 in $85 \%$ yield. Alkyne isomerization, using $\mathrm{KH}$ and $\mathrm{H}_{2} \mathrm{~N}\left(\mathrm{CH}_{2}\right)_{3} \mathrm{NH}_{2}$, followed by carboalumination and protection of the alcohol with TES-Cl gave 27 in $68 \%$ yield. Claisen condensation ${ }^{57}$ of ethyl hydrogen malonate and thiazolidinethione $\mathbf{3 1}$ gave the $\beta$-ketoester 32 in $85 \%$ yield. Selective formation of the $(Z)$ enol phosphate using lithium hexamethyldisilazide and $\mathrm{ClPO}(\mathrm{OEt})_{2}$ followed by $\mathrm{Fe}-$ catalzyed cross-coupling gave olefin 33 in $92 \%$ yield. Aldol addition, alcohol protection and acetylide addition yielded propargylyic alcohol 34 in $83 \%$ yield. Alcohol 34 was then subjected to protection, semi-hydrogenation, dihydroxylation and finally oxidative cleavage to give aldehyde $\mathbf{2 8}$ in $92 \%$ yield. The reaction of a grignard reagent derived from vinyl iodide 27 and aldehyde 28 gave alcohol 35 in 75\% yield. Silation of $\mathbf{3 5}$ with TBSOTf, followed by TES deprotection using PPTS and hydrolysis using LiOH gave 36 in 93\% yield. The Shiina procedure for macrolactonization followed by desilylation and oxidation gave $\mathbf{2 6}$ in $95 \%$ yield. 58 Treatment of 26 with $\mathrm{TBAF}$ at $-78{ }^{\circ} \mathrm{C}$ and warming to $5^{\circ} \mathrm{C}$ triggered the transannular cascade to give the tricyclic compound $\mathbf{3 7}$ as a single diastereomer in $95 \%$ yield. Enol $\mathbf{3 7}$ was deoxygenated to $\mathbf{3 8}$ using a sequence of triflate formation, catalytic reduction and conjugate reduction. Deprotection of 38, followed by oxidation and esterification afforded 8-epi-16 in $95 \%$ yield. Finally, epimerization of the $\mathrm{C} 8$ position with $\mathrm{K}_{2} \mathrm{CO}_{3}$ in $\mathrm{CH}_{3} \mathrm{OH}$, followed by acylation gave $\mathbf{1 2}$ in $78 \%$ yield.

In 2008, Hagiwara and co-workers also published a total synthesis of $\mathbf{1 2}$ in 20 steps with $0.15 \%$ yield. ${ }^{52}$ They envisioned 12 being synthesized from the hydroxy- ketone $\mathbf{3 9}$ through a linear series of functionalizations (Figure 5). Protection of the $(R)-(-)$-Wieland-Miescher ketone 59 followed by treatment with $\mathrm{NH}_{4} \mathrm{Cl}$ in $\mathrm{KOH}$ and $\mathrm{CH}_{3} \mathrm{OH}$ gave the hydroxy-ketone 39 in $73 \%$ yield (Scheme 2). A reductive alkylation of $\mathbf{3 9}$ gave a mixture of $\mathbf{4 0}$ and $\mathbf{4 1}$ in $21 \%$ and $51 \%$ yield, respectively. Compound $\mathbf{4 1}$ was then deprotected and the resulting diketone was 
subjected to double Wittig methylenation ${ }^{60}$ with NaHMDS and $\mathrm{Ph}_{3} \mathrm{PCH}_{3} \mathrm{Br}$ to give ester 42 which was immediately reduced with $\mathrm{LAH}$ and the corresponding diols protected to afford $\mathbf{4 3}$ in 54\% yield. Hydroboration followed by oxidation gave di-aldehyde $\mathbf{4 4}$ in $94 \%$ yield. Protection of the formyl groups, deprotection of the TBS ether and subsequent oxidation gave aldehyde $\mathbf{4 5}$ in $78 \%$ yield. The reaction of 3-lithiofuran with $\mathbf{4 5}$ gave the desired $12 S$ furylalcohol $\mathbf{4 6}$ and its $12 R$ epimer in 66\% yield and in a 2:3 ratio. Deprotection of the $S$ isomer of 46, followed by oxidation and esterification gave 2-desacetoxy salvinorin A $\mathbf{4 7}$ in $90 \%$ yield. Treatment of $\mathbf{4 7}$ with NaHMDS and TES-Cl in THF at $-78^{\circ}$ gave the corresponding silyl enol ether which was then subjected to Rubottom oxidation to yield 2-epi-17 ${ }^{61}$ in $70 \%$ yield. Inversion of the stereochemistry at $\mathrm{C} 2$ using Mitsunobu conditions ${ }^{62}$ followed by acylation, gave 12 in $86 \%$ yield.

Diterpenes are a diverse class of natural products with several subtypes, including neoclerodanes. Neoclerodane $\mathbf{1 2}$ serves as a useful example for the development of methodology to modify other neoclerodane diterpenes. Modifications to the structure of $\mathbf{1 2}$ have aided in determining its chemical reactivity as well as provide a platform for analogue development. Attempts to remove the $\mathrm{C} 2$ acetate of $\mathbf{1 2}$ with base leads to a mixture of products. This reaction was later optimized using $\mathrm{Na}_{2} \mathrm{CO}_{3}$ and $\mathrm{CH}_{3} \mathrm{OH}$. The $\mathrm{C} 1$ carbonyl of $\mathbf{1 2}$ can be selectively reduced and the $\mathrm{C} 4$ methyl ester has been converted to the corresponding acid. The C17 lactone may be selectively reduced using DIBAL-H. The furan ring of $\mathbf{1 2}$ may be reduced or oxidatively degraded to the C13 carboxylic acid. The total synthesis of $\mathbf{1 2}$ has been accomplished by two different groups and offers a strategy towards obtaining analogues of 12 that are otherwise inaccessible by semi-synthesis. Further advances in the synthesis of neoclerodane diterpenes are likely to further develop this structural class of terpenes into useful biological probes.

\section{Acknowledgments}

The authors would like to thank the National Institute of Health and the National Institute on Drug Abuse, as well as the Universities of Iowa and Kansas for financial support of our ongoing research efforts. AL is currently supported by NIDA grant DA018151S1.

\section{References and Notes}

1. Ruzicka L. Experientia 1953;9:357. [PubMed: 13116962]

2. Merritt AT, Ley SV. Nat. Prod. Rep 1992;9:243. [PubMed: 1436738]

3. Eisenreich W, Bacher A, Arigoni D, Rohdich F. Cell. Mol. Life Sci 2004;61:1401. [PubMed: 15197467]

4. Eisenreich W, Rohdich F, Bacher A. Trends Plant Sci 2001;6:78. [PubMed: 11173292]

5. Silver GM, Fall R. J. Biol. Chem 1995;270:13010. [PubMed: 7768893]

6. Koepp AE, Hezari M, Zajicek J, Vogel BS, LaFever RE, Lewis NG, Croteau R. J. Biol. Chem 1995;270:8686. [PubMed: 7721772]

7. Cavin C, Holzhaeuser D, Scharf G, Constable A, Huber WW, Schilter B. Food Chem. Toxicol 2002;40:1155. [PubMed: 12067578]

8. Wattenberg LW, Hanley AB, Barany G, Sparnins VL, Lam LK, Fenwick GR. Int. Symp. Princess Takamatsu Cancer Res. Fund 1985;16:193. [PubMed: 3916195]

9. Tokoroyama T. Synthesis 2000;5:611.

10. De la Torre MC, Hueso-Rodriguez JA, Rodriguez B, Servettaz O, Piozzi F, Savona G. Phytochemistry 1986;25:2239.

11. Barton DHR, Elad D. J. Chem. Soc 1956:2085.

12. Kohno H, Maeda M, Tanino M, Tsukio Y, Ueda N, Wada K, Sugie S, Mori H, Tanaka T. Cancer Lett 2002;183:131. [PubMed: 12065087]

13. Andersen NR, Lorck HOB, Rasmussen PR. J. Antibiot 1983;36:753. [PubMed: 6684107]

Bioorg Med Chem Lett. Author manuscript; available in PMC 2010 November 10. 
14. Kawada S, Yamashita Y, Ochiai K, Ando K, Iwasaki T, Takiguchi T, Nakano H. J. Antibiot 1995;48:211. [PubMed: 7730154]

15. Krishna Kumari GN, Balachandran J, Aravind S, Ganesh MR. J. Agric. Food. Chem 2003;51:1555. [PubMed: 12617583]

16. Jain DC, Tripathi AK. Phytother. Res 1993;7:327.

17. Cantrell CL, Klun JA, Bryson CT, Kobaisy M, Duke SO. J. Agric. Food. Chem 2005;53:5948. [PubMed: 16028979]

18. Cantrell CL, Klun JA, Pridgeon J, Becnel J, Green S 3rd, Fronczek FR. Chem. Biodivers 2009;6:447. [PubMed: 19353538]

19. Carroll JF, Cantrell CL, Klun JA, Kramer M. Exp. Appl. Acarol 2007;41:215. [PubMed: 17380408]

20. Hagiwara H, Hamano K, Nozawa M, Hoshi T, Suzuki T, Kido F. J. Org. Chem 2005;70:2250. [PubMed: 15760212]

21. Xiang AX, Watson DA, Ling T, Theodorakis EA. J. Org. Chem 1998;63:6774. [PubMed: 11672290]

22. Grossman RB, Rasne RM. Org. Lett 2001;3:4027. [PubMed: 11735576]

23. Valdes LJ 3rd, Diaz JL, Paul AG. J. Ethnopharmacol 1983;7:287. [PubMed: 6876852]

24. Valdes LJ 3rd. J. Nat. Prod 1986;49:171. [PubMed: 3701340]

25. Siebert DJ. J. Ethnopharmacol 1994;43:53. [PubMed: 7526076]

26. Valdes LJ 3rd. J. Psychoactive Drugs 1994;26:277. [PubMed: 7844657]

27. Prisinzano TE. Life Sci 2005;78:527. [PubMed: 16213533]

28. Roth BL, Baner K, Westkaemper R, Siebert D, Rice KC, Steinberg S, Ernsberger P, Rothman RB. Proc. Natl. Acad. Sci. U.S.A 2002;99:11934. [PubMed: 12192085]

29. Prisinzano TE, Tidgewell K, Harding WW. AAPS J 2005;7:E592. [PubMed: 16353938]

30. Tidgewell K, Harding WW, Schmidt M, Holden KG, Murry DJ, Prisinzano TE. Bioorg. Med. Chem. Lett 2004;14:5099. [PubMed: 15380207]

31. Beguin C, Richards MR, Wang Y, Chen Y, Liu-Chen LY, Ma Z, Lee DY, Carlezon WA Jr, Cohen BM. Bioorg. Med. Chem. Lett 2005;15:2761. [PubMed: 15869877]

32. Harding WW, Tidgewell K, Byrd N, Cobb H, Dersch CM, Butelman ER, Rothman RB, Prisinzano TE. J. Med. Chem 2005;48:4765. [PubMed: 16033256]

33. Harding WW, Tidgewell K, Schmidt M, Shah K, Dersch CM, Snyder J, Parrish D, Deschamps JR, Rothman RB, Prisinzano TE. Org. Lett 2005;7:3017. [PubMed: 15987194]

34. Lee DY, Karnati VV, He M, Liu-Chen LY, Kondaveti L, Ma Z, Wang Y, Chen Y, Beguin C, Carlezon WA Jr, Cohen B. Bioorg. Med. Chem. Lett 2005;15:3744. [PubMed: 15993589]

35. Munro TA, Goetchius GW, Roth BL, Vortherms TA, Rizzacasa MA. J. Org. Chem 2005;70:10057. [PubMed: 16292839]

36. Kutrzeba L, Dayan FE, Howell JL, Feng J, Giner J-L, Zjawiony JK. Phytochemistry 2007;68:1872. [PubMed: 17574635]

37. Munro TA, Rizzacasa MA, Roth BL, Toth BA, Yan F. J. Med. Chem 2005;48:345. [PubMed: 15658846]

38. Harding WW, Schmidt M, Tidgewell K, Kannan P, Holden KG, Gilmour B, Navarro H, Rothman RB, Prisinzano TE. J. Nat. Prod 2006;69:107. [PubMed: 16441078]

39. Tidgewell K, Harding WW, Lozama A, Cobb H, Shah K, Kannan P, Dersch CM, Parrish D, Deschamps JR, Rothman RB, Prisinzano TE. J. Nat. Prod 2006;69:914. [PubMed: 16792410]

40. Beguin C, Duncan KK, Munro TA, Ho DM, Xu W, Liu-Chen LY, Carlezon WA Jr, Cohen BM. Bioorg. Med. Chem. Lett 2009;17:1370.

41. Bikbulatov RV, Yan F, Roth BL, Zjawiony JK. Bioorg. Med. Chem. Lett 2007;17:2229. [PubMed: 17303418]

42. Brown L. 1984

43. Valdes LJ 3rd, Butler WM, Hatfield GM, Paul AG, Koreeda M. J. Org. Chem 1984;49:4716.

44. Holden KG, Tidgewell K, Marquam A, Rothman RB, Navarro H, Prisinzano TE. Bioorg. Med. Chem. Lett 2007;17:6111. [PubMed: 17904842]

45. Harding WW, Schmidt M, Tidgewell K, Kannan P, Holden KG, Dersch CM, Rothman RB, Prisinzano TE. Bioorg. Med. Chem. Lett 2006;16:3170. [PubMed: 16621556] 
46. Simpson DS, Katavic PL, Lozama A, Harding WW, Parrish D, Deschamps JR, Dersch CM, Partilla JS, Rothman RB, Navarro H, Prisinzano TE. J. Med. Chem 2007;50:3596. [PubMed: 17580847]

47. Lozama A, Prisinzano TE. Unpublished results. 2009

48. Prisinzano TE, Rothman RB. Chem. Rev 2008;108:1732. [PubMed: 18476672]

49. Bergman YE, Mulder R, Perlmutter P. J. Org. Chem 2009;74:2589. [PubMed: 19231873]

50. Lingham AR, Hügel HM, Rook TJ. Aust. J. Chem 2006;59:340.

51. Scheerer JR, Lawrence JF, Wang GC, Evans DA. J. Am. Chem. Soc 2007;129:8968. [PubMed: 17602636]

52. Nozawa M, Suka Y, Hoshi T, Suzuki T, Hagiwara H. Org. Lett 2008;10:1365. [PubMed: 18311991]

53. Burns AC, Forsyth CJ. Org. Lett 2008;10:97. [PubMed: 18062692]

54. Evans DA, Rajapakse HA, Stenkamp D. Angew. Chem., Int. Ed. Engl 2002;41:4569. [PubMed: 12458541]

55. Evans DA, Rajapakse HA, Chiu A, Stenkamp D. Angew. Chem., Int. Ed. Engl 2002;41:4573. [PubMed: 12458542]

56. Ho T. Tandem Organic Reactions 1992:33.

57. Claisen L. Ber. Deutsch. Chem. Ges 1881;14:2460.

58. Shiina I, Kubota M, Ibuka R. Tetrahedron Lett 2002;43:7535.

59. Wieland P, Miescher K. Helv. Chim. Acta 1950;33:2215.

60. Wittig G, Schöllkopf U. Chem. Ber 1954;87:1318.

61. Rubottom GM, Vazquez MA, Pelegrina DR. Tetrahedron Lett 1974;15:4319.

62. But TY, Toy PH. J. Am. Chem. Soc 2006;128:9636. [PubMed: 16866510] 


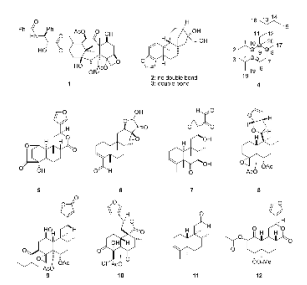

Figure 1.

Structures of taxol (1), cafestol (2), kahweol (3), diterpene skeleton (4), columbin (5), clerocidin (6), terpentecin (7), neoclerodanes clerodin (8), ajugatansin A1 (9), tafricanin A1 (10), callicarpenal (11) and salvinorin A (12). 


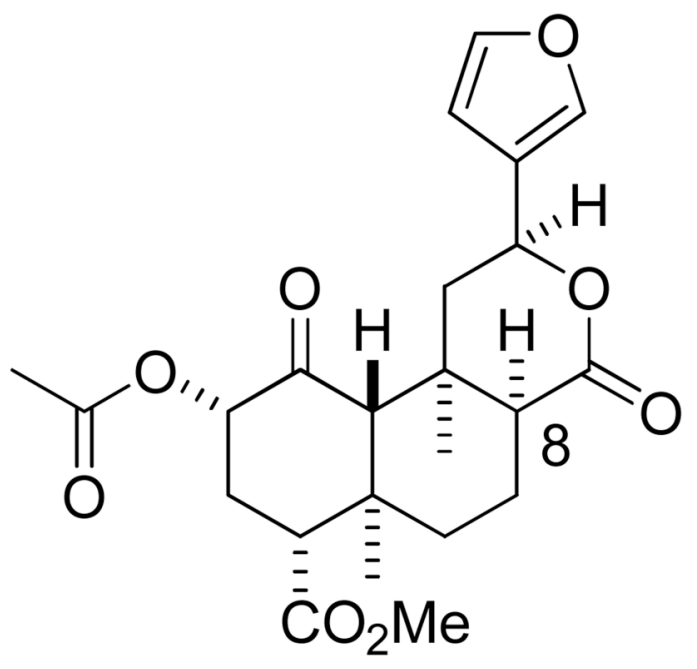

\section{8-epi-12}

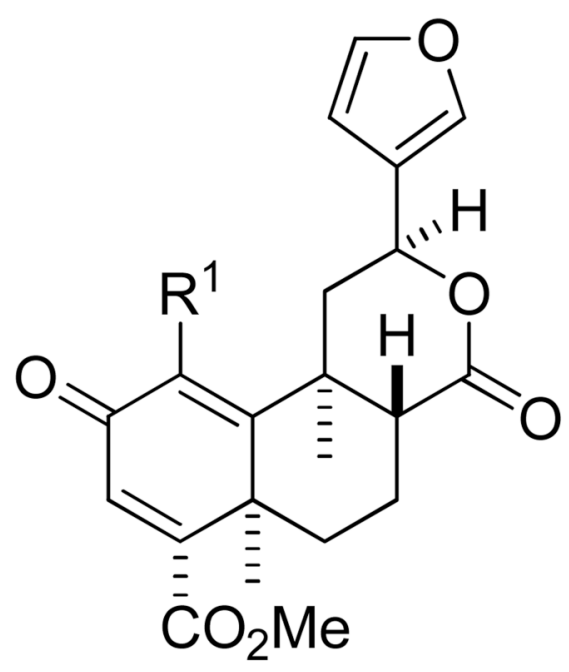

14a: $\mathbf{R}^{1} \quad \mathrm{OH}$

\section{4b: $\mathbf{R}^{2} \quad H$}

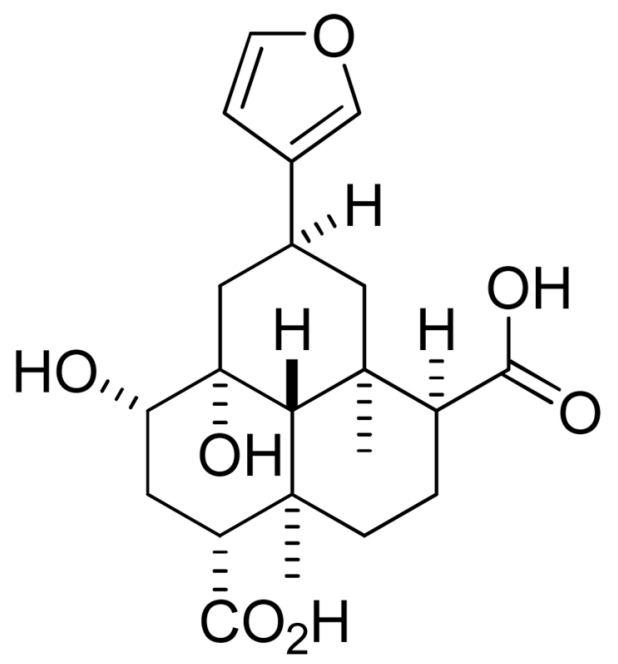

13

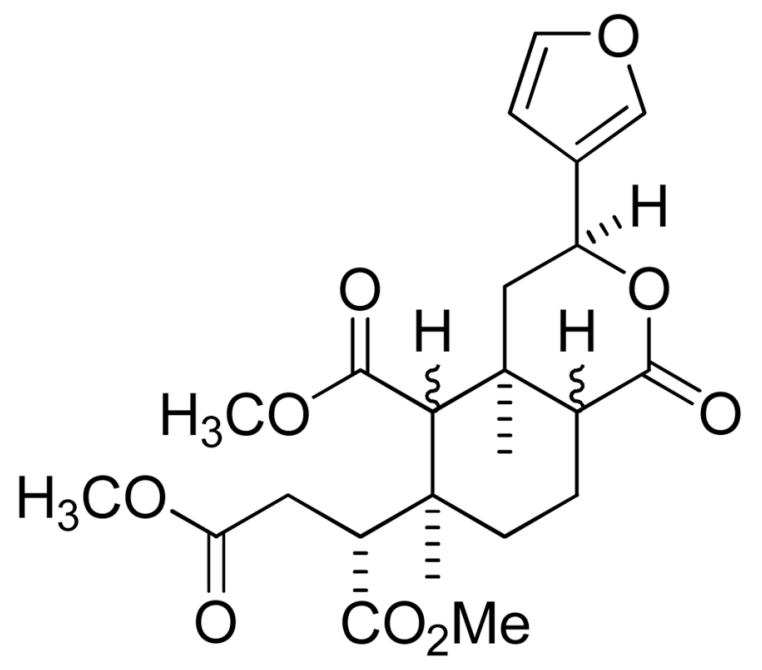

15

Figure 2.

Compounds obtained through basic hydrolysis of $\mathbf{1 2}$. 


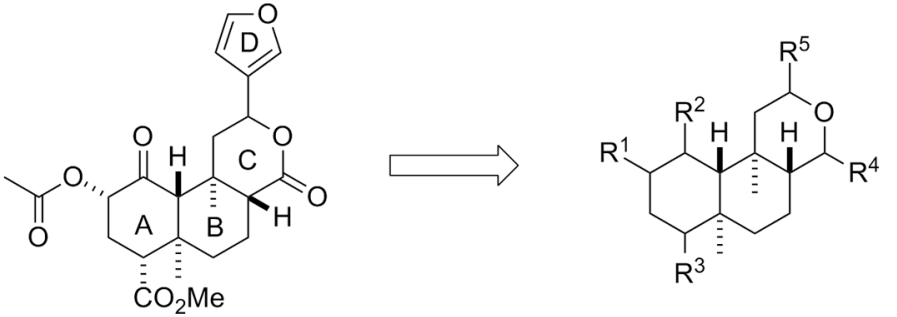

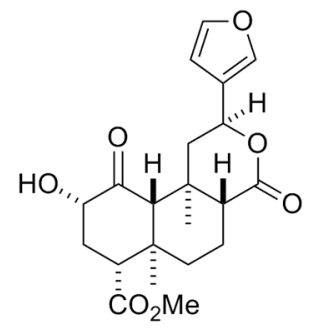

16

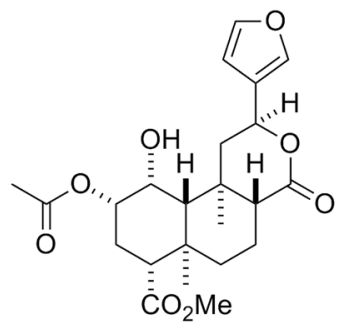

17<smiles>CC(=O)O[C@@H]1C[C@@H]2C(=O)[C@@H]3[C@@H]4C[C@H](c5ccoc5)OC(=O)C43CC[C@@]2(O)[C@H](C(=O)O)C1</smiles>

18

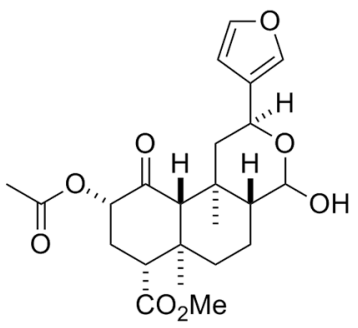

19<smiles>COC(=O)[C@@H]1C[C@@H](OC(C)=O)C(=O)[C@H]2[C@@H]3C[C@H](C(=O)O)OC(=O)[C@H]3CC[C@@]21C(C)=O</smiles>

20

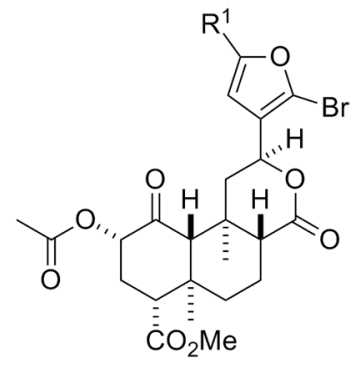

23<smiles>COC(=O)[C@H]1C[C@@H](OC(C)=O)C(=O)[C@H]2[C@@H]3C[C@H](C4CCOC4)OC(=O)[C@H]3CC[C@@]12O</smiles>

21

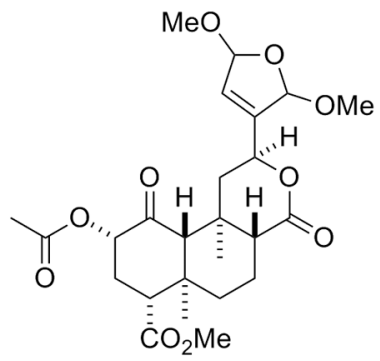

24<smiles>COC[C@]12CCC(C(=O)O)(C(=O)O)[C@H](CCC3CCOC3)[C@@H]1C(=O)[C@@H](OC(C)=O)C[C@@H]2OC</smiles>

22

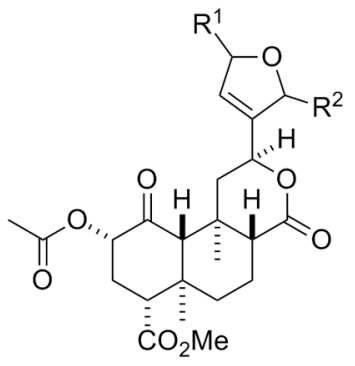

25

25a: $R^{1}=\mathrm{H}, \mathrm{OH} ; \mathrm{R}^{2}=\mathrm{O}$

25b: $R^{1}=\mathrm{O} ; \mathrm{R}^{2}=\mathrm{H}, \mathrm{OH}$

Figure 3.

Structures of selected modifications to $\mathbf{1 2}$. 


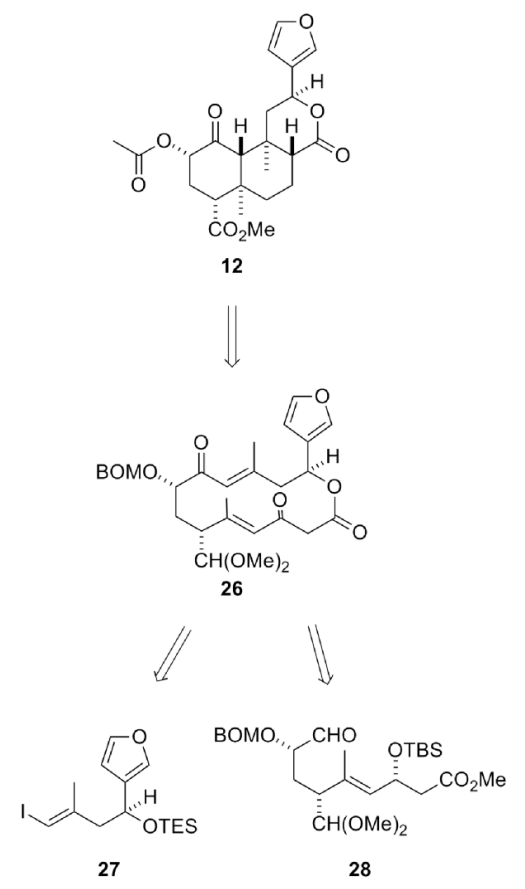

Figure 4.

Retrosynthesis of $\mathbf{1 2}$ as proposed by Scheerer et al. ${ }^{50}$ 

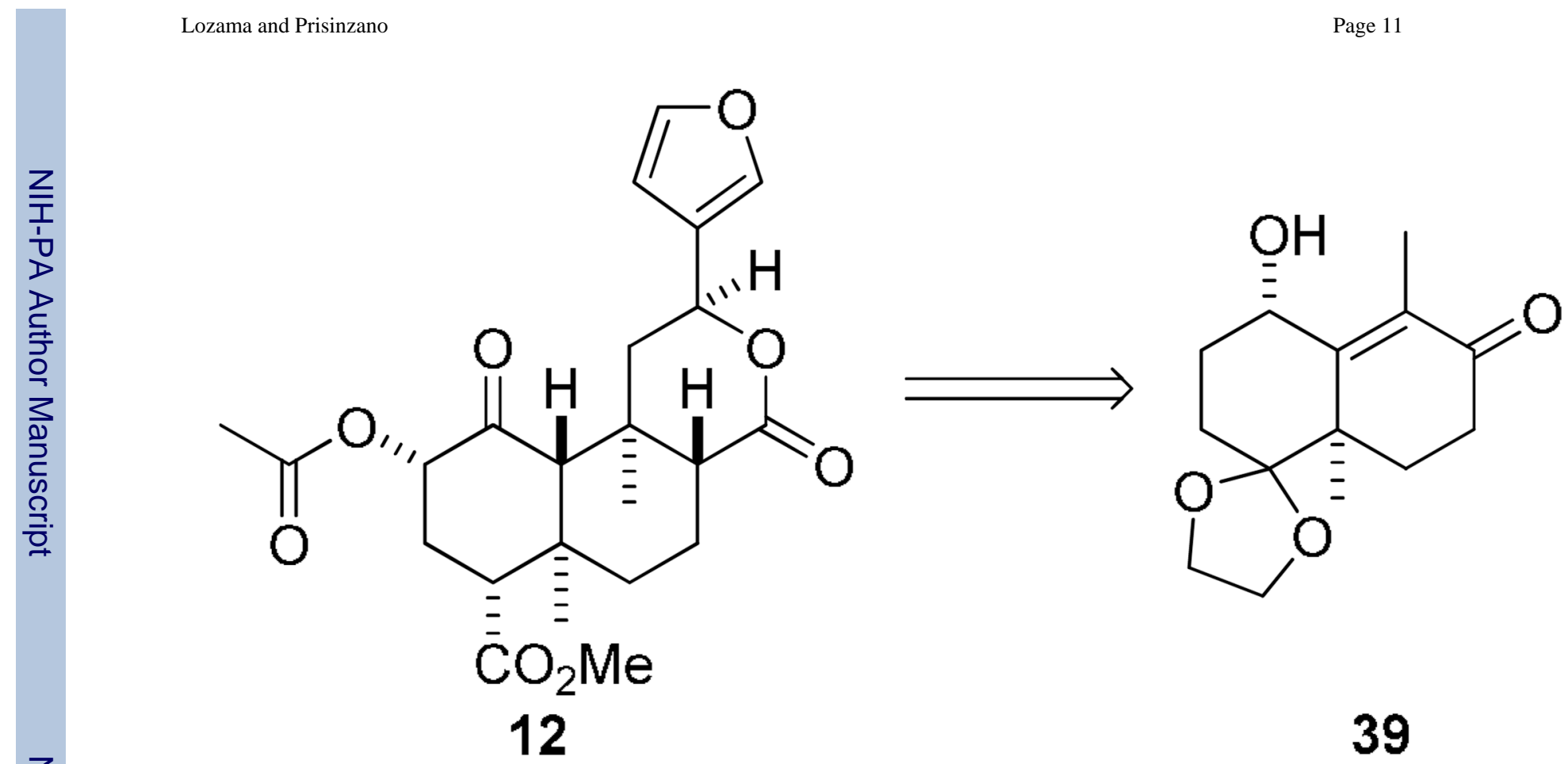

Figure 5.

Retrosynthesis of $\mathbf{1 2}$ as proposed by Nozawa et al. ${ }^{51}$ 
<smiles>O=Cc1ccoc1</smiles><smiles>CC#CC(=O)c1ccoc1</smiles>

29

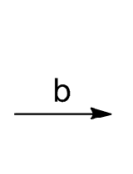

$$
\text { , }
$$

32<smiles>C=CCCC(=O)N1CCSC1=S</smiles>

31<smiles>[Z7]C[C@H](C)[C@H](O)c1ccoc1</smiles>

30
36

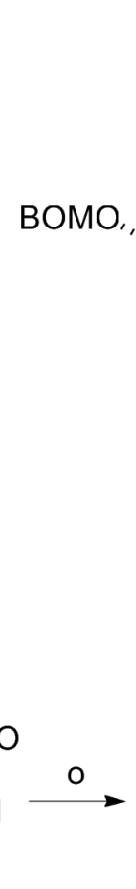

37

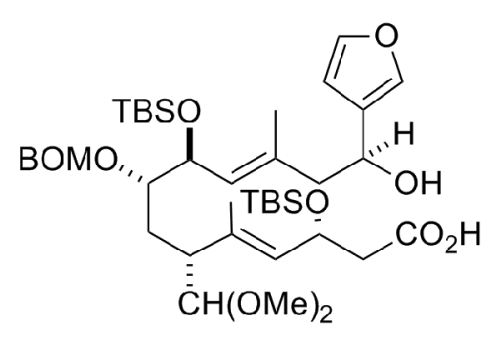<smiles>COC[C@]12CC(O)=C3C(=O)O[C@H](c4ccoc4)C[C@]3(C)[C@H]1C(=O)[C@@H](OC)C[C@H]2C</smiles><smiles>C=CC[C@H](C(C)=CC(=O)OCC)C(C)C</smiles>

33
34

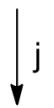

28
BOMO.<smiles>CC(C)[C@@H]1[C@@H]2C[C@@H](c3ccoc3)OC(=O)[C@@H]2CC[C@@H]1C(C)C</smiles>

38

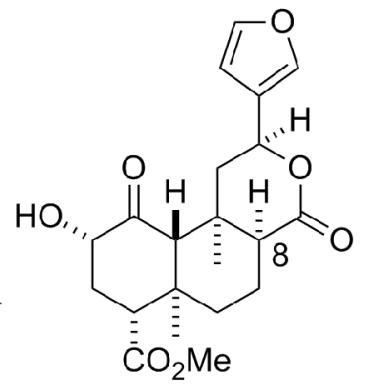

8-epi-16

Scheme 1.

Synthesis of 12 by Scheerer et al. ${ }^{50}$ Reagents and conditions: (a) propyne, $n$-BuLi, Et ${ }_{2} \mathrm{O},-78$ ${ }^{\circ} \mathrm{C}$; (b) (R)- $\beta$-Methyl-CBS catalyst, $\mathrm{BH}_{3} \bullet \mathrm{Me}_{2} \mathrm{~S},-30{ }^{\circ} \mathrm{C}$; (c):(1) $\mathrm{KH}, \mathrm{H}_{2} \mathrm{~N}\left(\mathrm{CH}_{2}\right)_{3} \mathrm{NH}_{2}, 0{ }^{\circ} \mathrm{C}$; (2) $\mathrm{Me}_{3} \mathrm{Al}, \mathrm{Cp}-{ }_{2} \mathrm{ZrCl}_{2}, \mathrm{I}_{2},-45^{\circ} \mathrm{C}$; (3) TESCl, imidazole; (d) Ni-(R)-BINAP(OTf) $2,2,6-$ lutidine, $\mathrm{BF}_{3} \bullet \mathrm{OEt}_{2}, \mathrm{HC}(\mathrm{OMe})_{3}$; (e) $\mathrm{HO}_{2} \mathrm{CCH}_{2} \mathrm{CO}_{2} \mathrm{Et}, i$-PrMgCl, $65^{\circ} \mathrm{C}$; (f) LiHMDS ; ClPO $(\mathrm{OEt})_{2} ;$ (g) $\mathrm{Fe}(\mathrm{acac})_{3}, \mathrm{MeMgCl},-20{ }^{\circ} \mathrm{C}$; (h):(1) DIBAL-H, $-78^{\circ} \mathrm{C}$; (2) $\mathrm{MnO}_{2}$; (3) $\mathrm{Sn}$ (OTf) $2, N$-ethylpiperidine, chiral auxiliary, $-78^{\circ} \mathrm{C}$; (i): (1) TBSOTf, 2,6-lutidine; (2) $\mathrm{K}_{2} \mathrm{CO}_{3}, \mathrm{CH}_{3} \mathrm{OH}$; (3) $\mathrm{OsO}_{4}, \mathrm{NMO}, \mathrm{NaIO}_{4}$; (4) $\mathrm{Zn}(\mathrm{OTf})_{2}$, (-)-N-Methyl-ephedrine, Et $3 \mathrm{~N}$, 4phenyl-1-butyne; (j):(1) BOMCl, NaHMDS, $-78{ }^{\circ} \mathrm{C}$; (2) Lindlar catalyst, $\mathrm{H}_{2}$; (3) $\mathrm{K}_{2} \mathrm{OsO}_{4}$, $\mathrm{NMO}$, citric acid, $50{ }^{\circ} \mathrm{C}, \mathrm{Pb}(\mathrm{OAc})_{4}, \mathrm{~K}_{2} \mathrm{CO}_{3}$; (k) 27, $n$-BuLi, $\mathrm{MgBr}^{\circ} \mathrm{OEt}_{2}, \mathrm{CH}_{2} \mathrm{Cl}_{2},-78$ to $0^{\circ}$ 
C; (1): (1) TBSOTf, 2,6-lutidine; (2) PPTS, $\mathrm{CH}_{3} \mathrm{OH}$; (3) LiOH, $i$-PrOH, $\mathrm{H}_{2} \mathrm{O}$; (m):(1) MNBA, DMAP, [0.0015 M]; (2) TBAF; (3) Dess-Martin periodinane; (n) TBAF, -78 to $5{ }^{\circ} \mathrm{C}$; (o): (1) $\mathrm{NaH}$, Comins reagent; (2) $\mathrm{Pd}(\mathrm{OAc})_{2}$, dppf, $\mathrm{Et}_{3} \mathrm{SiH}$; (3) L-selectride, $t$ - BuOH, -78 to $-55^{\circ} \mathrm{C}$; (p) $\mathrm{LiBF}_{4}$, acetonitrile/ $\mathrm{H}_{2} \mathrm{O}$; (q) $\mathrm{NaClO}_{2}, \mathrm{TMSCHN}_{2}$; (r) $\mathrm{K}_{2} \mathrm{CO}_{3}, \mathrm{CH}_{3} \mathrm{OH}$; (s) $\mathrm{Ac}_{2} \mathrm{O}$, pyridine, DMAP. 
<smiles>C=C1C(=O)CC[C@]2(C)C(=O)CCCC2=C1C</smiles><smiles>CCOC(=O)C[C@]12CCC(=O)[C@@]3(CCC=C31)OCCO2</smiles>

40

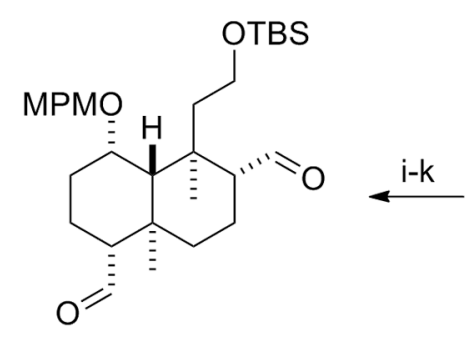

44<smiles>[Y16]O[C@H]1CCC(=C)[C@@]2(C)CCC(=C)[C@H](CC[OH2+])[C@H]12</smiles>

43<smiles>CCOC(=O)C[C@H]1C(=O)CC[C@]23OCCOC12CC[C@H](O)[C@H]3O</smiles>

41

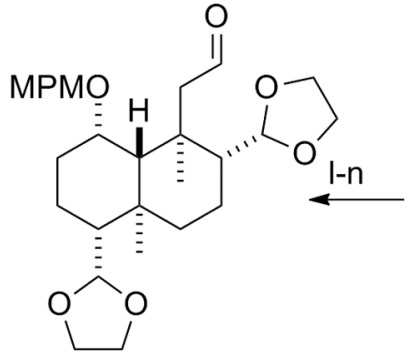

45<smiles>C1CCOCC1</smiles>

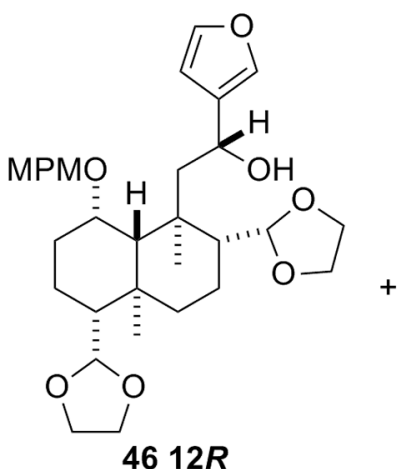

$4612 R$<smiles>CO[C@H]1CC[C@H](C2OCCO2)[C@@]2(C)CC[C@H](C3OCCO3)[C@H](C[C@H](O)c3ccoc3)[C@]12C</smiles>

$4612 S$

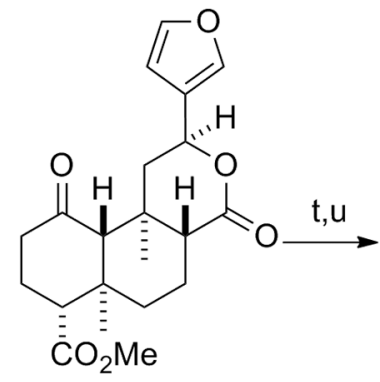

47

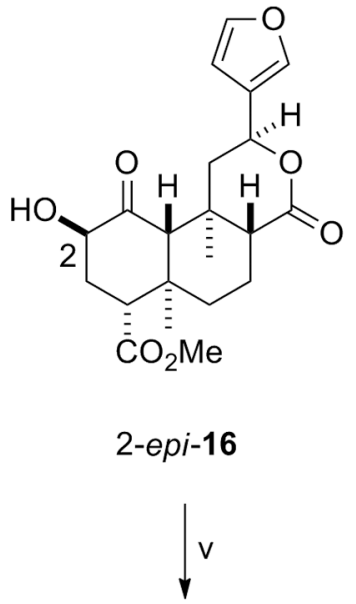

12

Scheme 2.

Synthesis of 12 by Nozawa et al. ${ }^{51}$ Reagents and conditions: (a) $\left(\mathrm{CH}_{2}\right)_{2}(\mathrm{OTMS})_{2}, \mathrm{Me}_{3} \mathrm{SiOTf}$, $15 \mathrm{Kbar}, 40{ }^{\circ} \mathrm{C}$; (b) $\mathrm{KOH}, \mathrm{CH}_{3} \mathrm{OH} / \mathrm{H}_{2} \mathrm{O}, 65^{\circ} \mathrm{C}$; (c) $\mathrm{Li} / \mathrm{NH}_{3}$, THF, $-78^{\circ} \mathrm{C}$, alkyl iodide; (d) $3 \mathrm{M}$ $\mathrm{HCl}$ aqueous EtOH; (e) $\mathrm{NaHMDS}, \mathrm{Ph}_{3} \mathrm{PCH}_{3} \mathrm{Br}$, THF; (f) LAH, Et $2 \mathrm{O}, 0{ }^{\circ} \mathrm{C}$; (g) TBSCl, DMAP, $\mathrm{Et}_{3} \mathrm{~N}, \mathrm{CH}_{2} \mathrm{Cl}_{2}$ (h) $\mathrm{NaH}, \mathrm{MPMCl}$, DMF; (i)BH 3 , tetrahydrofuran, $3 \mathrm{M} \mathrm{NaOH}, \mathrm{H}_{2} \mathrm{O}_{2}$; (j) PDC,

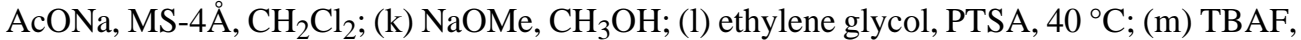

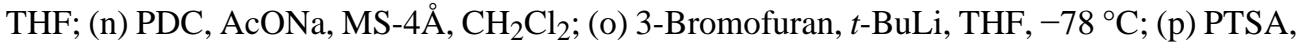
acetone, $\mathrm{H}_{2} \mathrm{O}$, reflux; (q) DDQ, $\mathrm{H}_{2} \mathrm{O}, \mathrm{CH}_{2} \mathrm{Cl}_{2}, 0{ }^{\circ} \mathrm{C}$; (r) PDC, 2-methyl-2-butene, DMA; (s) DCC, DMAP, $\mathrm{CH}_{3} \mathrm{OH}, \mathrm{CH}_{2} \mathrm{Cl}_{2}$; (t) NaHMDS, TESCl, THF; (u) $m$-CPBA, $\mathrm{NaHCO}_{3}$, toluene, $\mathrm{H}_{2} \mathrm{O}, 0{ }^{\circ} \mathrm{C}, \mathrm{AcOH}$; (v) $\mathrm{PPh}_{3}$, DIAD, $\mathrm{AcOH}, \mathrm{CH}_{2} \mathrm{Cl}_{2}$. 